\title{
Time Delay and Cost Overrun of Road over Bridge (ROB) Construction Projects in India
}

\author{
*Chandrasekaran Balaji Venkateswaran and Rajiah Murugasan
}

\begin{abstract}
Published online: 24 November 2017
To cite this article: Chandrasekaran Balaji Venkateswaran and Rajiah Murugasan. (2017). Time delay and cost overrun of road over bridge (ROB) construction projects in India. Journal of Construction in Developing Countries, 22(Supp. 1): 79-96. https://doi.org/10.21315/jcdc2017.22.supp 1.5
\end{abstract}

To link to this article: https://doi.org/10.21315/jcdc2017.22.supp 1.5

\begin{abstract}
This paper aims at studying the factors that contribute to time delay and cost overrun of Road over Bridge (ROB) projects in India. Data for the research study were collected from 62 respondents, including owners, contractors, and consultants of ROB projects. The literature survey and the questionnaire survey helped in identifying 29 factors. The topmost factors were ranked based on the frequency of occurrences. The correlation among owners, contractors, and consultants on ranking of factors was derived by Spearman rank correlation. Factor analysis was used to classify the factors into groups and identify the key groups responsible for time delay and cost overrun of projects. This study will help all stakeholders of ROB projects in India to understand the factors and thereby reduce time delay and cost overrun as well as expedite their completion.
\end{abstract}

Keywords: Time delay, Cost overrun, Road over bridges, Land acquisition, Infrastructure projects

\section{INTRODUCTION}

Road over bridges (ROBs) are grade-separated bridge structures constructed primarily over railway level crossings (LC) on major roads like National Highways and State Highways. They facilitate the traffic to pass the LC locations without any waiting. They are essential when the Train Vehicle Unit (TVU) exceeds 100,000, which is usually higher on the urban stretches of National Highways and State Highways. At a location, which warrants construction of an ROB, the delay in its construction leads to long waiting hours for the traffic, loss of man hours, and slow industrial output. Occasionally, loss of human lives also occurs due to accidents at LCs.

In India, construction of an ROB is abnormally delayed at several locations, even up to years, for various reasons. The status report of the Ministry of Road Transport and Highways, Government of India (MORT\&H), as on March 2010 shows that out of 224 National Highway Development Projects (NHDP) that includes ROBs, 168 projects underwent cost overrun, 148 projects underwent time delay, and 20 projects were subjected to time delay and cost overrun (Kishore, Rao and Singh, 2012). This fact indicates that $75 \%$ of the projects have an overrun. The secondary data collected by the present authors on 57 ROB construction projects, which were constructed during 2010-2015 in India, revealed that 95\% of the ROB projects were subjected to time delay, $70 \%$ to cost overrun, and $100 \%$ to either time delay or cost overrun. It is evident that time delays and cost overruns have more or less become a common feature of ROB construction projects in India.

Department of Civil Engineering, Anna University, Chennai, Tamil Nadu, INDIA

"Corresponding author: bakrkaku@gmail.com 
Thus far, no significant research has been undertaken on time delay and cost overrun of ROB construction projects in India. Hence, this study investigates the causes of their time delay and cost overrun and suggests suitable measures for their fast completion.

\section{LITERATURE REVIEW}

Many studies on time delay and cost overrun of infrastructure projects reveal that time delays and cost overruns occur in all types of construction projects and they are also more project-specific. A brief overview of such studies from 2004 to 2015 is given below.

Flyvbjerg, Holm and Buhl (2004) conducted a major study on cost overrun of 258 infrastructure projects in 20 countries. They estimated that the average cost escalation was $45 \%$ for rail projects, $34 \%$ for fixed link projects (tunnels and bridges), and $30 \%$ for road projects. They observed that the cost escalation was a global phenomenon across 20 nations on 5 continents. They emphasized that cost escalation was a rule rather than an exception. With regard to construction industry, they found that the time delay and the cost overrun were major problems in 9 out of every 10 projects. It is not surprising that cost escalation has not decreased over the past 70 years.

Le-Hoa, Lee and Lee (2008) studied time delay and cost overrun of 87 construction projects in Vietnam. Based on a questionnaire survey, they identified five most important causes of time delay and cost overrun of Vietnamese construction projects: (i) poor site management and supervision, (ii) poor project management assistance, (iii) financial difficulties of owner, (iv) financial difficulties of contractor, and ( $v$ ) design changes. Based on factor analysis, they further concluded that the slowness and lack of constraint, incompetence, design, market and estimate, financial capability, the government, and the worker as the principal factors contributing to the time delay and cost overrun of construction projects in Vietnam.

Singh (2009) investigated the various issues related to time delays and cost overruns in publicly-funded infrastructure projects in India. He analysed a dataset of 894 projects from 17 infrastructure sectors. He revealed that the contractual and the institutional failures were the primary causes of time delays and cost overruns.

Fugar and Baah (2010) employed a questionnaire survey to seek the views of clients, contractors, and consultants on the relative importance of the factors on delays in construction projects in Ghana. They showed that financing was the most influential factor causing delay in construction projects. According to them, material factors were the second most important causes for delay, followed by scheduling and controlling factors.

Based on a questionnaire survey, Akoa (2011) examined the key causes of time delays and cost overruns in highway and bridge projects in Cameroon. He concluded that time delays and cost overruns varied with the type of project, project ownership, funding source, and project size.

Mahamid and Bruland (2012) investigated the cost deviation in road construction projects in Palestine. They obtained data from 169 road construction projects awarded in the West Bank during 2004-2008. They observed that $100 \%$ of projects suffered due to cost escalation. The primary reason was inefficient estimation: $76 \%$ projects were underestimated and $24 \%$ were overestimated. 
Wijekoon and Attanayake (2012) examined cost overrun on road construction projects in Sri Lanka. They noted factors influencing cost overruns in road projects through a literature survey. Further, they used a questionnaire survey to identify significant factors influencing cost overruns in road projects. According to them, the critical factors were delays in making payment, delays in utility relocation, and design changes during the construction phase, cost escalation, and land acquisition-related issues.

Kishore, Rao and Singh (2012) analysed the factors responsible for the time and cost overrun of the NHDP executed all over India. They collected primary and secondary data through a questionnaire survey administered to contractors, consultants, and government agencies. Furthermore, they analysed the data and identified the most influential factors. They concluded that the delays were mostly found in preconstruction activities such as land acquisition, shifting of utilities, and contractor's poor performance. They also remarked that cost overruns were prevalent mainly in the initial phases of NHDP, particularly in East West (EW) corridors.

Choudhry, Nasir and Gabriel (2012) explored time delays and cost overruns in highway projects in Pakistan through a questionnaire survey. They collected responses from 25 contractors, 21 consultants, and 10 clients. They ranked a total of 30 time delays and 28 cost overrun factors using the relative importance index (RII). They revealed that scope changes and additional work, inappropriate government policies and priorities, improper planning, price escalations on essential construction materials, and land acquisition were major factors for time delays and cost overruns. According to them, the most important causes were delay in making payments to contractors, the conditions under force majeure, financial difficulties faced by clients, and land acquisition and settlement.

Ramanathan, Narayanan and Idrus (2012) studied time delay and cost overrun of construction projects with a critical review of 41 studies from around the world. They listed 113 causes for delays, and classified them into 18 groups. In addition, they used a questionnaire survey to collect responses and analysed them to rank the problem factors. Moreover, they investigated whether the identified causes were valid for projects executed in Sabah, East Malaysia.

Patil et al. (2013) examined the causes of delay in Indian transportation infrastructure projects extensively. Based on the literature review, they prepared a questionnaire with 64 possible causes. After analysis of data, they concluded that the problem of delays in transportation infrastructure projects was frequent and notable. According to them, the five most important causes of construction delays in transportation infrastructure projects were: (i) land acquisition, (ii) environmental impact of the project, (iii) financial closure and change of orders by the client, (iv) poor site management, and (v) poor supervision of contractors.

Honrao and Desai (2015) studied delay in execution of infrastructure projects in India and identified the delays caused by owners, contractors and consultants, services and utilities, the government regulations, and the external environment. They concluded that cost overrun, time overrun, disruption of traffic movement, and disputes were the main causes of delay in execution of infrastructure projects in India.

Dutta and Dutta (2015) investigated the causes of time delays and cost overruns in transportation sector projects in Bangladesh and identified project size, organisational failures, and economic factors as the main causes. 
Although the above literature review does not focus on ROB as a separate entity, it provides the base for the investigation of time delays and cost overruns in infrastructure projects. The factors identified as responsible for time delays and cost overruns in the select research studies are furnished in Table 1. It is very clear from the literature survey that time delays and cost overruns are commonly encountered in almost all construction projects in the world. Therefore, this study investigates the major factors of time delays and cost overruns in ROB construction as a whole.

Table 1. Factors Identified as Responsible for Time Delay and Cost Overrun

\begin{tabular}{|c|c|c|c|c|}
\hline S. No. & Authors & Study Area & $\begin{array}{l}\text { Samples } \\
\text { Considered }\end{array}$ & $\begin{array}{l}\text { Factors Identified as Responsible for } \\
\text { Time Delay and Cost Overrun }\end{array}$ \\
\hline 1 & $\begin{array}{l}\text { Le-Hoai, Lee } \\
\text { and Lee } \\
(2008)\end{array}$ & Vietnam & 87 & $\begin{array}{l}\text { 1. Slow payment of completed works } \\
\text { 2. Poor contract management } \\
\text { 3. Obsolete or unsuitable construction } \\
\text { 4. } \text { methods } \\
\text { 5. Poor site management and supervision } \\
\text { 6. Slow information flow between parties } \\
\text { 7. Poor project management assistance } \\
\text { 8. Mistakes in design } \\
\text { 9. Design changes } \\
\text { 10. Additional works } \\
\text { 11. Shortage of materials } \\
\text { 12. Inaccurate estimates } \\
\text { 13. Price fluctuations } \\
\text { 14. Financial difficulties of contractor } \\
\text { 15. Financial difficulties of owner } \\
\text { 16. Obstacles from government } \\
\text { 17. Shortage of skilled workers }\end{array}$ \\
\hline 2 & Singh (2009) & India & 894 & $\begin{array}{l}\text { 1. Technical and natural factors } \\
\text { 2. Contractual failures } \\
\text { 3. Organizational/institutional failures } \\
\text { 4. Economic factors }\end{array}$ \\
\hline 3 & $\begin{array}{l}\text { Fugar and } \\
\text { Baah (2010) }\end{array}$ & Ghana & 130 & $\begin{array}{l}\text { 1. Delay in honouring certificates } \\
\text { 2. Underestimation of the costs of } \\
\text { 3. Undects } \\
\text { projects } \\
\text { 4. Difficulty in accessing bank credit } \\
\text { 5. Poor supervision } \\
\text { 6. Underestimation of time for completion } \\
\text { of projects by contractors } \\
\text { 7. Shortage of materials } \\
\text { 8. Poor professional management } \\
\text { 9. Fluctuation of prices/rising cost of } \\
\text { 10. Poor site management }\end{array}$ \\
\hline
\end{tabular}


Table 1. (continued)

\begin{tabular}{|c|c|c|c|c|}
\hline S. No. & Authors & Study Area & $\begin{array}{l}\text { Samples } \\
\text { Considered }\end{array}$ & $\begin{array}{l}\text { Factors Identified as Responsible for } \\
\text { Time Delay and Cost Overrun }\end{array}$ \\
\hline 4 & Akoa (2011) & Cameroon & 61 & $\begin{array}{l}\text { 1. Negligence of site visits before/during } \\
\text { the bidding process-unknown site } \\
\text { conditions } \\
\text { 2. Weak and insufficient technical studies } \\
\text { 3. Lack of project planning/programming } \\
\text { 4. Underestimating of cost estimates and } \\
\text { schedules/overestimating of benefits } \\
\text { 5. Lack of equipment } \\
\text { 6. Bidding procedures }\end{array}$ \\
\hline 5 & $\begin{array}{l}\text { Mahamid } \\
\text { and Bruland } \\
(2012)\end{array}$ & Palestine & 40 & $\begin{array}{l}\text { 1. Materials price fluctuation, insufficient } \\
\text { time for estimate } \\
\text { 2. Experience in contracts } \\
\text { 3. Size of contract } \\
\text { 4. Incomplete drawings }\end{array}$ \\
\hline 6 & $\begin{array}{l}\text { Wijekoon } \\
\text { and } \\
\text { Attanayake } \\
\text { (2012) }\end{array}$ & Sri Lanka & 44 & $\begin{array}{l}\text { 1. Payment delays } \\
\text { 2. Delay in shifting existing utilities } \\
\text { 3. Cost escalation } \\
\text { 4. Design changes during construction } \\
\text { 5. Issues in land acquisition }\end{array}$ \\
\hline 7 & $\begin{array}{l}\text { Kishore, Rao } \\
\text { and Singh } \\
(2012)\end{array}$ & India & 66 & $\begin{array}{ll}\text { 1. } & \text { Land acquisition } \\
\text { 2. } & \text { Detailed project reports } \\
\text { 3. Contractual problems } \\
\text { 4. Financial management } \\
\text { 5. Capacity constraints } \\
\text { 6. Law and order }\end{array}$ \\
\hline 8 & $\begin{array}{l}\text { Choudhry, } \\
\text { Nasir and } \\
\text { Gabriel } \\
\text { (2012) }\end{array}$ & Pakistan & 56 & $\begin{array}{l}\text { 1. Additional work } \\
\text { 2. Inappropriate government policies } \\
\text { 3. Lack of priorities } \\
\text { 4. Improper planning } \\
\text { 5. Price escalation of construction } \\
\text { 6. Laterials and/or price adjustment } \\
\text { 7. Inconsistent cash flows } \\
\text { 8. Delay in decision by client } \\
\text { 9. Design errors and changes } \\
\text { 10. Inaccurate estimation } \\
\text { 11. Relocation of services and utilities } \\
\text { 12. Delay in progress payments } \\
\text { 13. Extreme weather, law and order (force } \\
\text { 14. Conajeure) } \\
\text { 15. Financial difficulties faced by clients } \\
\text { 16. Ineffective planning and scheduling } \\
\text { 17. Scope changes and additional work } \\
\text { 18. Delay in handing over site to the } \\
\text { 19. Dentractor } \\
\text { 19. }\end{array}$ \\
\hline
\end{tabular}


Table 1. (continued)

\begin{tabular}{llll}
\hline S. No. $\quad$ Authors & Study Area & $\begin{array}{c}\text { Samples } \\
\text { Considered }\end{array}$ & $\begin{array}{c}\text { Factors Identified as Responsible for } \\
\text { Time Delay and Cost Overrun }\end{array}$ \\
\hline 9 Ramanathan, Malaysia & 41 & 1. & Finance \\
Narayanan & 2. Projects \\
and ldrus & 3. Project attributes \\
$(2012)$ & 4. Owner/client \\
& 5. Contractor \\
& 6. Consultants \\
& 7. Design related \\
& 8. Coordination \\
& 9. Materials \\
& 10. Plant/equipment \\
& 11. Labour/manpower \\
& 12. Environment \\
13. Contract related \\
14. Contractual relationship \\
15. External factors \\
16. Changes in policies/plans \\
17. Scheduling and controlling \\
18. Government relationship
\end{tabular}

\section{OBJECTIVES OF THE STUDY}

The objectives of the study are:

1. To identify and rank the factors causing time delay and cost overrun in ROB construction projects in the Indian context.

2. To study the correlation between the responses of various stakeholders to time delay and cost overrun in the construction of ROBs in India.

3. To classify the factors into distinct groups based on the correlation matrix using factor analysis.

4. To recommend corrective measures to stakeholders in order to reduce the time delay and cost overrun of ROB construction projects in India.

\section{METHODOLOGY}

The methodology for the present study was evolved by combining the methods followed by Akoa (2011), Le-Hoai, Lee and Lee (2008), and Wijekoon and Attanayake (2012) in their studies on time delay and cost overrun of key infrastructure projects.

The factors that generally contribute to time delay and cost overrun of infrastructure construction projects, including ROB projects, were identified. The standard international practice of conducting a questionnaire survey was adopted to obtain views of the respondents on factors responsible for time delay and cost overrun of ROB construction projects in India (Akoa, 2011). The questionnaire survey was distributed to owners, contractors, and consultants who were involved in the construction of ROB projects. The respondents were requested to add additional factors, if any, and to give a rating (weightage) (Le-Hoai, Lee and Lee, 2008) from their experience for all factors causing time delay and cost overrun of ROB 
construction projects. In addition to the 22 factors from the questionnaire survey, 7 more were added by respondents making a total of 29 factors covering various stages of planning, bidding, and execution of ROB construction projects.

A five-point Likert scale (Le-Hoai, Lee and Lee, 2008) was used to rate the responses with a rating of 1 for totally agree, 2 for agree, 3 for neither, 4 for disagree, and 5 for totally disagree.

Frequency of response was assessed by using the following frequency index (Wijekoon and Attanayake 2012):

$$
\text { Frequency index }(F I)=\frac{\sum a\left|\frac{n}{N}\right|}{5}
$$

where,

$A=$ constant expressing the weight assigned to each response (ranges from 1 for totally disagree to 5 for totally agree);

$\mathrm{n}$ = frequency of each response; and

$\mathrm{N}=$ total number of responses.

The Statistical Package for the Social Sciences (SPSS) was used to identify the foremost causes (Le-Hoai, Lee and Lee, 2008). Based on the frequency index, factors were ranked. The degree of agreement or disagreement between owners, consultants, and contractors on ranking of factors was verified using Spearman rank correlation. Furthermore, statistical analyses were performed using factor analysis on SPSS for grouping the factors, so that a meaningful interpretation of the responses could be obtained. Bartlett's test of sphericity was used to test the suitability of data for the factor analysis and the Kaiser-Meyer-Olkin test was used to assess the sampling adequacy for factor analysis (Le-Hoai, Lee and Lee, 2008).

\section{Survey Participants}

The survey was conducted with various stakeholders of ROB construction projects in India. The list of prominent stakeholders from whom the responses were received is given below:

1. Department of Highways, Government of Tamil Nadu

2. National Highways Authority of India (NHAI), Government of India

3. Ministry of Road Transport and Highways, Government of India

4. Ministry of Railways, Government of India

5. Larsen \& Toubro, ECC Division

6. M. N. Dastur Company Ltd.

7. CDM Smith Ltd.

8. Other contractors of ROB projects.

A total of 95 questionnaires was distributed to owners, consultants, and contractors through email and in person. Out of 95 people, 62 responded to the survey. The response rate was $65.26 \%$, which was good, as a response rate of more than $40 \%$ is acceptable (Akoa, 2011 ). 


\section{Tests for Normality}

The data considered for the study were assumed to be normal as the sample size considered was more than 30 (Ghasemi and Zahedias, 2012). Similarly, the median of all the $Z$ values of Skewness and Kurtosis lies between 1.33 and 0.162 , respectively, which are well within the allowable score of +1.67 and -1.67 .

\section{Time Delay and Cost Overrun Factors}

From the literature review, the following 22 factors were identified as responsible for time delay and cost overrun of construction projects, which are applicable to ROB projects also.

1. Lack of project planning

2. Inadequate project planning

3. Underestimation of cost/schedules

4. Weak/insufficient technical studies

5. Poor project implementation strategies

6. Mistakes/discrepancies in various stages

7. Bidding procedures

8. Long duration of bidding process

9. Lowest bid price system

10. Unreasonable adjustment of price by contractors

11. Negligence of site visit

12. Mismanagement by inexperienced supervisors

13. Lack of equipment and machinery

14. Poor communication among stakeholders

15. Unethical activities

16. Change in scope of contracts

17. Construction errors and on-site testing approval

18. Proposal on unexpected sites

19. Shortage of materials

20. Material price fluctuation

21. Methods of payment

22. Weather conditions

The following seven additional factors were added as responsible for time delay and cost overrun of ROB projects from the questionnaire survey conducted with contractors, consultants, and government agencies.

1. Delay due to land acquisition process

2. Cost of land acquisition

3. Legal hurdles

4. Many stakeholders

5. Claims and disputes by stakeholders

6. Unclear terms and conditions of contracts

7. Displacement of existing network of infrastructure 


\section{DATA ANALYSIS}

The data analysis was performed for three purposes: ranking, correlation, and factor analysis.

Table 2. Frequency Index (FI) and Ranking

\begin{tabular}{|c|c|c|c|c|c|c|c|}
\hline S No. & Factors & $\begin{array}{c}\text { Fl for } \\
\text { Consultants }\end{array}$ & $\begin{array}{l}\text { Fl for } \\
\text { Owners }\end{array}$ & $\begin{array}{c}\text { Fl for } \\
\text { Contractors }\end{array}$ & $\begin{array}{l}\text { Ranking for } \\
\text { Consultants }\end{array}$ & $\begin{array}{l}\text { Ranking } \\
\text { for Owners }\end{array}$ & $\begin{array}{l}\text { Ranking for } \\
\text { Contractors }\end{array}$ \\
\hline 1 & Lack of project planning & 0.756 & 0.704 & 0.706 & 5 & 13 & 10 \\
\hline 2 & $\begin{array}{l}\text { Inadequate project } \\
\text { planning }\end{array}$ & 0.744 & 0.719 & 0.682 & 7 & 9 & 12 \\
\hline 3 & $\begin{array}{l}\text { Delay due to land } \\
\text { acquisition process }\end{array}$ & 0.933 & 0.882 & 0.953 & 1 & 1 & 1 \\
\hline 4 & Cost of land acquisition & 0.633 & 0.630 & 0.577 & 16 & 20 & 19 \\
\hline 5 & Legal hurdles & 0.700 & 0.756 & 0.835 & 10 & 5 & 4 \\
\hline 6 & $\begin{array}{l}\text { Weak/insufficient } \\
\text { technical studies }\end{array}$ & 0.578 & 0.474 & 0.482 & 23 & 29 & 25 \\
\hline 7 & $\begin{array}{l}\text { Underestimation of cost/ } \\
\text { schedules }\end{array}$ & 0.600 & 0.600 & 0.506 & 21 & 25 & 23 \\
\hline 8 & $\begin{array}{l}\text { Poor project } \\
\text { implementation } \\
\text { strategies }\end{array}$ & 0.633 & 0.630 & 0.682 & 16 & 20 & 12 \\
\hline 9 & $\begin{array}{l}\text { Mistakes/discrepancies } \\
\text { in various stages }\end{array}$ & 0.533 & 0.541 & 0.435 & 27 & 27 & 27 \\
\hline 10 & Bidding procedures & 0.511 & 0.652 & 0.671 & 28 & 17 & 13 \\
\hline 11 & $\begin{array}{l}\text { Duration of bidding } \\
\text { process }\end{array}$ & 0.544 & 0.593 & 0.529 & 26 & 26 & 21 \\
\hline 12 & Lowest bid price system & 0.489 & 0.600 & 0.647 & 29 & 25 & 15 \\
\hline 13 & $\begin{array}{l}\text { Unreasonable } \\
\text { adjustment of price by } \\
\text { contractors }\end{array}$ & 0.656 & 0.711 & 0.294 & 13 & 10 & 29 \\
\hline 14 & Negligence of site visit & 0.611 & 0.719 & 0.624 & 19 & 9 & 17 \\
\hline 15 & $\begin{array}{l}\text { Mismanagement } \\
\text { by inexperienced } \\
\text { supervisors }\end{array}$ & 0.667 & 0.667 & 0.647 & 12 & 16 & 15 \\
\hline 16 & $\begin{array}{l}\text { Claims and disputes by } \\
\text { stakeholders }\end{array}$ & 0.756 & 0.778 & 0.824 & 5 & 2 & 5 \\
\hline 17 & Many stakeholders & 0.767 & 0.704 & 0.882 & 3 & 13 & 2 \\
\hline 18 & $\begin{array}{l}\text { Poor communication } \\
\text { among stakeholders }\end{array}$ & 0.744 & 0.719 & 0.741 & 7 & 9 & 7 \\
\hline 19 & Unethical activities & 0.722 & 0.756 & 0.706 & 9 & 5 & 10 \\
\hline 20 & $\begin{array}{l}\text { Unclear terms and } \\
\text { conditions of contracts }\end{array}$ & 0.544 & 0.630 & 0.459 & 26 & 20 & 26 \\
\hline 21 & $\begin{array}{l}\text { Change in scope of } \\
\text { contracts }\end{array}$ & 0.800 & 0.748 & 0.765 & 2 & 6 & 6 \\
\hline
\end{tabular}


Table 2. (continued)

\begin{tabular}{cccccccc}
\hline S No. & \multicolumn{1}{c}{ Factors } & $\begin{array}{c}\text { Fl for } \\
\text { Consultants }\end{array}$ & $\begin{array}{c}\text { Fl for } \\
\text { Owners }\end{array}$ & $\begin{array}{c}\text { Fl for } \\
\text { Contractors }\end{array}$ & $\begin{array}{c}\text { Ranking for } \\
\text { Consultants }\end{array}$ & $\begin{array}{c}\text { Ranking } \\
\text { for Owners }\end{array}$ & $\begin{array}{c}\text { Ranking for } \\
\text { Contractors }\end{array}$ \\
\hline 22 & $\begin{array}{l}\text { Displacement of existing } \\
\text { network of infrastructure }\end{array}$ & 0.733 & 0.763 & 0.847 & 8 & 3 & 3 \\
23 & $\begin{array}{l}\text { Construction errors and } \\
\text { on site testing approval }\end{array}$ & 0.678 & 0.622 & 0.518 & 11 & 21 & 22 \\
24 & $\begin{array}{l}\text { Proposal on unexpected } \\
\text { sites }\end{array}$ & 0.622 & 0.607 & 0.400 & 18 & 23 & 28 \\
25 & $\begin{array}{l}\text { Shortage of materials } \\
26\end{array}$ & 0.589 & 0.607 & 0.718 & 22 & 23 & 8 \\
27 & $\begin{array}{l}\text { Material price fluctuation } \\
28\end{array}$ & 0.644 & 0.682 & 0.635 & 14 & 14 & 16 \\
& $\begin{array}{l}\text { Lack of equipment and } \\
\text { machinery }\end{array}$ & 0.622 & 0.667 & 0.541 & 18 & 16 & 28 \\
29 & Weather conditions & 0.600 & 0.704 & 0.600 & 21 & 13 & 18 \\
\hline
\end{tabular}

\section{Ranking of Factors}

The data were analysed using SPSS 19 software. The responses from the questionnaire survey were classified under owners, consultants, and contractors. There were 27 respondents from the owner category, 18 from the consultant category, and 17 from the contractor category. The frequency index (FI) and its ranking for each category were calculated for each factor and are given in Table 2. The leading factors, considering the Fl of each category of respondents are given in Table 3.0.

Table 3. Leading Factors

\begin{tabular}{lccc}
\hline \multicolumn{1}{c}{ Causes } & $\begin{array}{c}\text { Ranking by } \\
\text { Consultants }\end{array}$ & $\begin{array}{c}\text { Ranking } \\
\text { by Owners }\end{array}$ & $\begin{array}{c}\text { Ranking by } \\
\text { Contractors }\end{array}$ \\
\hline Delay due to land acquisition process & 1 & 1 & 1 \\
Many stakeholders & 3 & 13 & 2 \\
Displacement of existing network of infrastructure & 8 & 3 & 3 \\
Legal hurdles & 10 & 5 & 4 \\
Claims and disputes by stakeholders & 5 & 2 & 5 \\
\hline
\end{tabular}

\section{Correlation between Owners, Consultants and Contractors}

The degree of agreement between owners, consultants, and contractors on the ranking of causes was verified using Spearman rank correlation. The results of analysis through SPSS are given in Table 4. The coefficient of correlation, which is more than 0.50 (Le-Hoai, Lee and Lee, 2008) shows that there is a considerable correlation among owners, consultants, and contractors on the ranking of causes for the time delay and cost overrun of ROB construction projects in India. 
Table 4. Correlation Analysis

\begin{tabular}{|c|c|c|c|c|c|}
\hline & & & $\begin{array}{c}\text { Rank of } \\
\text { Consultants }\end{array}$ & $\begin{array}{l}\text { Rank of } \\
\text { Owners }\end{array}$ & $\begin{array}{c}\text { Rank of } \\
\text { Contractors }\end{array}$ \\
\hline \multirow{9}{*}{$\begin{array}{l}\text { Spearman's } \\
\text { rho }\end{array}$} & \multirow{3}{*}{$\begin{array}{l}\text { Rank of } \\
\text { consultants }\end{array}$} & Correlation coefficient & 1.000 & $.788^{* *}$ & $.672^{* *}$ \\
\hline & & Sig. (2-tailed) & $\cdot$ & .000 & .000 \\
\hline & & $\mathrm{N}$ & 29 & 29 & 29 \\
\hline & \multirow{3}{*}{$\begin{array}{l}\text { Rank of } \\
\text { owners }\end{array}$} & Correlation coefficient & $.788^{* *}$ & 1.000 & $.709^{* *}$ \\
\hline & & Sig. (2-tailed) & .000 & . & .000 \\
\hline & & $\mathrm{N}$ & 29 & 29 & 29 \\
\hline & \multirow{3}{*}{$\begin{array}{l}\text { Rank of } \\
\text { contractors }\end{array}$} & Correlation coefficient & $.672^{* *}$ & $.709 * *$ & 1.000 \\
\hline & & Sig. (2-tailed) & .000 & .000 & . \\
\hline & & $N$ & 29 & 29 & 29 \\
\hline
\end{tabular}

Note: ${ }^{* *}$ Correlation is significant at 0.01 level (2-tailed)

\section{Factor Analysis}

This study identified 29 causes as responsible for time delay and cost overrun of ROB projects. As the number of causes was high, they were reduced to a few groups by a factor analysis using SPSS software. The suitability of the data for the factor analysis was assessed by Kaiser-Meyer-Olkin (KMO) and Bartlett's tests in SPSS. The test results are given in Table 5.

Table 5. Sampling Adequacy

\begin{tabular}{lcc}
\hline \multicolumn{3}{c}{ KMO and Bartlett's Tests } \\
\hline Kaiser-Meyer-Olkin measure of sampling adequacy & .600 \\
& Approx. Chi-Square & 493.279 \\
Bartlett's test of sphericity & df & 231 \\
& Sig. & .000 \\
\hline
\end{tabular}

It is evident from the results that the sampling adequacy is more than 0.50 (Williams, Brown and Onsman, 2010) and they have significance at 0.000. Therefore, the data were suitable for factor analysis. In order to derive the comprehensive and interpretable results from the factor analysis, the correlation matrix was formed with only 22 causes out of 29 . Seven causes did not have even a single value of correlation more than 0.30 and so were left out of analysis (Yong and Pearce, 2013). The values of total variance by factor analysis with the remaining 22 causes are given in Table 6. The Eigen values are more than 1.0 for 7 factors (groups) derived out of 22 causes. Therefore 22 causes are arranged into 7 factors (groups) in the results of the factor analysis. Table 7 shows the rotated component matrix of seven extracted factors (groups). 
Table 6. Total Variance

\begin{tabular}{ccccccccccc}
\hline & \multicolumn{3}{c}{ Initial Eigen Values } & \multicolumn{3}{c}{$\begin{array}{c}\text { Extraction Sums of Squared } \\
\text { Loadings }\end{array}$} & \multicolumn{3}{c}{$\begin{array}{c}\text { Rotation Sums of Squared } \\
\text { Loadings }\end{array}$} \\
\cline { 2 - 10 } & Total & $\begin{array}{c}\% \text { of } \\
\text { Variance }\end{array}$ & $\begin{array}{c}\text { Cumulative } \\
\%\end{array}$ & Total & $\begin{array}{c}\% \text { of } \\
\text { Variance }\end{array}$ & $\begin{array}{c}\text { Cumulative } \\
\%\end{array}$ & Total & $\begin{array}{c}\% \text { of } \\
\text { Variance }\end{array}$ & $\begin{array}{c}\text { Cumulative } \\
\%\end{array}$ \\
\hline 1 & 3.971 & 18.049 & 18.049 & 3.971 & 18.049 & 18.049 & 2.758 & 12.537 & 12.537 \\
2 & 2.789 & 12.677 & 30.727 & 2.789 & 12.677 & 30.727 & 2.502 & 11.372 & 23.909 \\
3 & 2.426 & 11.029 & 41.756 & 2.426 & 11.029 & 41.756 & 2.241 & 10.185 & 34.094 \\
4 & 1.928 & 8.763 & 50.519 & 1.928 & 8.763 & 50.519 & 2.098 & 9.538 & 43.633 \\
5 & 1.498 & 6.811 & 57.330 & 1.498 & 6.811 & 57.330 & 2.082 & 9.462 & 53.095 \\
6 & 1.392 & 6.328 & 63.659 & 1.392 & 6.328 & 63.659 & 1.777 & 8.078 & 61.173 \\
7 & 1.100 & 5.001 & 68.660 & 1.100 & 5.001 & 68.660 & 1.647 & 7.487 & 68.660 \\
\hline
\end{tabular}

The leading factors show that the factors identified in this study are fairly desirable with at least three variables per factor for most of the factors (Yong and Pearce, 2013). The loading values of less than 0.550 were left out of the analysis. The factors were then named by considering the causes in each factor (group) as shown in Table 7.

\section{RESULTS AND DISCUSSION}

Table 2 provides the list of the foremost factors influencing the time delay and cost overrun of ROB construction projects in India. The five leading factors identified from the data analysis are given in Table 3 and described below.

First, land acquisition of an ROB construction project is the most significant factor. Acquisition of land for a project is cumbersome and difficult in India. If the project area falls within private lands, it is much more difficult as owners tend to resist land acquisition in several ways. In urban locations, very few lands are under the control of the government and hence most of the ROB projects require land acquisition. Hence, several ROB projects are completed after inordinate delay, way beyond the scheduled completion period, resulting in considerable time delay and cost overrun.

Second, multiple stakeholders are involved in an ROB project. The major stakeholders in the ROB projects are local bodies, telephone authorities, drinking water infrastructure authorities, drainage infrastructure authorities, electricity distribution authorities, highways authorities, and railway authorities. Their consent and cooperation are essential for the successful completion of an ROB project. In the absence of an exclusive authority, with necessary powers, to bring all stakeholders of the project under its control, the shifting process often exceeds the stipulated time frame.

Third, in an ROB construction project, depending on the location of the project, shifting of a number of already existing infrastructures, owned by many agencies, falling under the project area is crucial. Further, each stakeholder has a set of specific guidelines for shifting the infrastructure. Delay due to the displacement of an existing network of infrastructure can be better addressed by timely completion of shifting of utilities falling in the project area of ROB, ahead of the commencement of the project. 


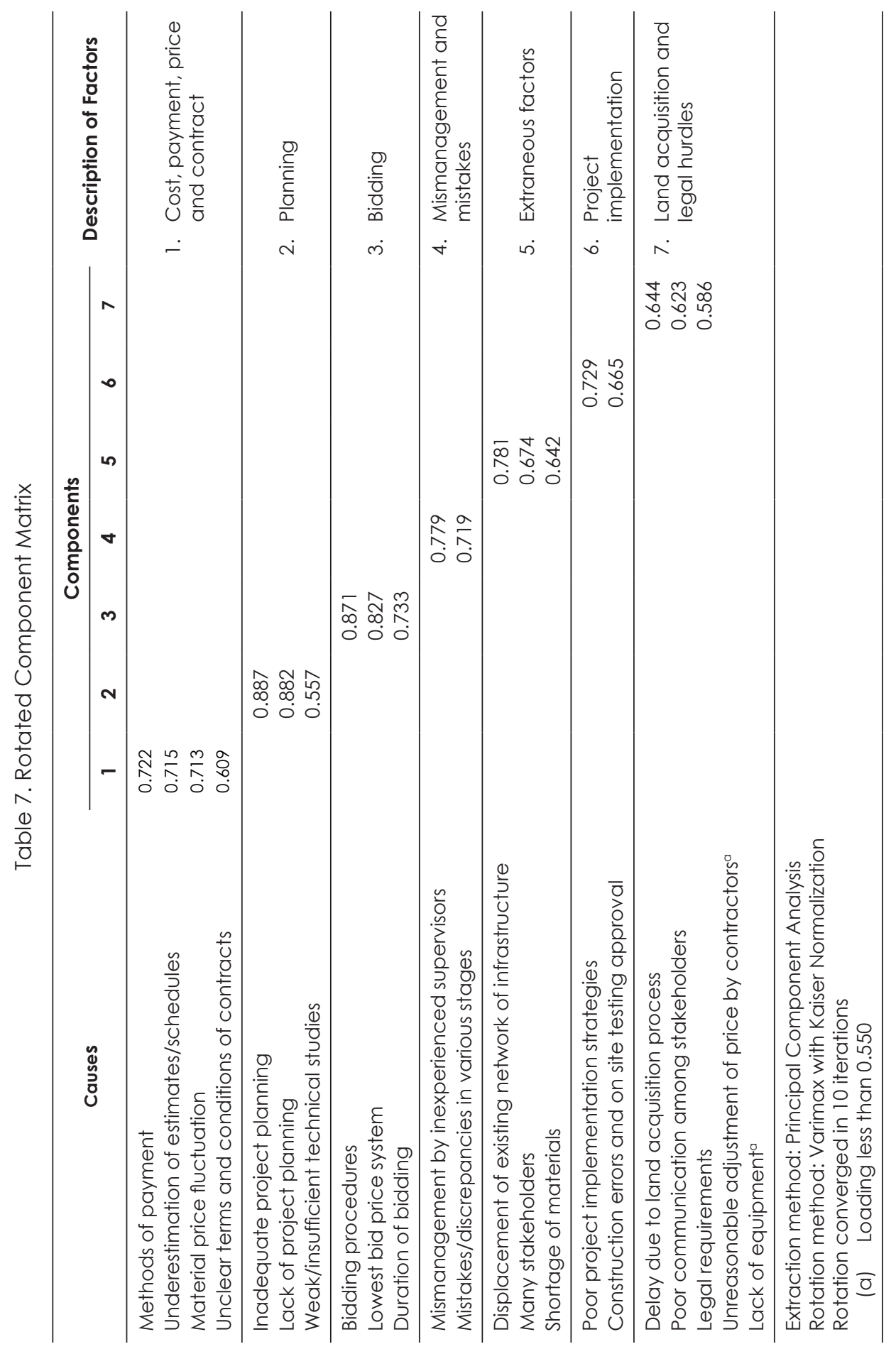


Fourth, legal hurdles for an ROB construction project come in the form of an objection by private owners to transfer their land for the project. An effective mechanism to handle legal hurdles is also necessary. Fifth, undue and unnecessary claims and disputes cause delay and cost overrun. This can be addressed by better resolution, better monitoring, and early resolution of disputes between stakeholders of the ROB project. On whole, the overall project management process has to be improved at every stage with adequate and best decision making mechanism.

\section{Results of Factor Analysis}

The results of the factor analysis are discussed below.

\section{Group I from Factor Analysis}

This group is named cost, payment, price, and contract which includes (i) methods of payment to contractors, (ii) underestimation of cost and schedules, (iii) material price fluctuation, and (iv) unclear contracts. The payment to the contractor is delayed for want of letter of credit (LOC) from the owner. Similarly, underestimation of quantity and cost of items could require revised sanction of estimates from the owner. As a result, payment for the revised quantity is made only after getting necessary approval for payment, leading to slow progress of work. In addition, material price escalation leads to increase in cost of materials such as cement, steel, aggregates, etc. Likewise, unclear terms and conditions of contract may lead to disputes while executing the ROB project. All these causes eventually result in time delay and cost overrun of the ROB project.

\section{Group II from Factor Analysis}

This group is named planning which consists of (i) inadequate project planning, (ii) lack of project planning, and (iii) weak/insufficient technical studies. Inadequate project planning and lack of planning reflect the deficiency in planning various activities of an ROB construction project such as construction of Reinforced Cement Concrete (RCC) trestle portion, retaining wall, formation of approaches using earthen embankments, bituminous surfacing, construction of service road, forming utility drains, shifting of project infrastructure, etc.

Depending upon the location of an ROB project, land acquisition, shifting of drinking water pipelines, sewage pipelines, shifting of lamp posts and transformers, etc., are essential. These activities are done concurrently on commencement of the project. Lack of planning in the completion of land acquisition and shifting of utilities will delay the project, even for years, far beyond the scheduled completion of the project, causing time delay and cost overrun.

Weak technical studies lead to wrong design of project components. Deficiency in the technical studies is mainly due to weak sub-soil exploration resulting in wrong selection of foundation for the ROB structure. This could be revealed during confirmatory soil exploration performed before execution of the project. Weak technical studies may require redesign of the structural components of the ROB, leading to time delay and cost overrun of the project. 


\section{Group III from Factor Analysis}

This group is named bidding, which includes (i) bidding procedures, (ii) lowest bid price system, and (iii) duration of bidding. Generally, in India, the lowest bidder is awarded work with acceptable percentages of cost above/below the estimate cost. As a result, in some situations, the bidder who has less professional expertise is awarded the work. Such bidder tends to delay the work on various stages. Some ROB projects could not be awarded to contractors due to lacklustre project benefits. In such a case, several tender calls may be required to finalise the contract for the project. As a result, bidding duration often exceeds the planned bidding time. This leads to delay and cost overrun of an ROB project. Hence, bidding procedures and longer duration of bidding also lead to delay and cost overrun of the project.

\section{Group IV from Factor Analysis}

This group is named mismanagement and mistakes, which include the causes (i) mismanagement by inexperienced supervisors and (ii) mistakes/discrepancies in various stages. Inadequate mobilisation of resources, wrong location of machinery, wrong prioritisation of various components of works, inefficient supervision, deficiency in the timely payment of wages to workers, and failure in logistics may lead to time delay and cost overrun of an ROB construction project. Mistakes/discrepancies during the feasibility study stage, design stage, estimate stage, bidding stage, project planning stage, and in the construction stage could lead to considerable time delay and cost overrun of the ROB construction project.

\section{Group V from Factor Analysis}

This group is named extraneous factors, which include (i) displacement of the existing network of infrastructure, (ii) many stakeholders, and (iii) shortage of materials. The displacement of the existing network of infrastructure may lead to enormous time delay and cost overrun, if proper planning is not done to shift them beyond the project area before the commencement of the ROB project. Depending on the location of the ROB project, stakeholders of the project may be numerous and they increase with the number of utility infrastructures. Another extraneous factor that could contribute to the time delay and cost overrun is the sudden and unexpected shortage of manpower necessary and materials used in the construction of the ROB.

\section{Group VI from Factor Analysis}

This group is named project implementation that includes (i) poor project implementation strategies and (ii) construction errors and on-site testing approval.

Failure to implement the project management techniques or lack of project management techniques, unrealistic and unscientific calculation of activities in project management, lack of monitoring and review of the project activities, inadequate steps to remove the hurdles to the scheduled completion of the project activities and failure to address the problems specific to the site of construction could lead to time delay and cost overrun of the ROB construction project. 
Construction errors in an ROB project such as incorrect marking of piers/ abutment locations and their sizes, error in detailing of reinforcement for structural components, incorrect setting out of curves by inexperienced engineers could slow down the progress of a project and thus contribute to the time delay and cost overrun of a project. If an ROB project is planned in a city/town without any provision for alternative diversion road, it could lead to traffic chaos in the construction area and could also delay the construction activity.

Quality control and mandatory approval during construction of an ROB, the requirement of on-site testing of various materials such as concrete, aggregates, steel, etc., consequent approval of the test results, and conducting initial/routine pile load test, in the case of pile foundation during the construction of an ROB, could lead to time delay and cost overrun of an ROB project. If the testing and approval activities are delayed beyond the scheduled completion time, naturally, the project will also be delayed resulting in time delay and cost overrun.

\section{Group VII from Factor Analysis}

This group is named land acquisition and legal hurdles, which include (i) delay due to land acquisition process, (ii) poor communication among stakeholders, and (iii) legal requirements.

Depending upon the location of an ROB project and the need for land for its construction, authorities/owners tend to acquire private lands. This involves several procedures such as identification of the land owners, obtaining willingness of the land owners to transfer their land for the project, publication in local newspapers for objection, if any, from anybody for land acquisition, conducting private negotiations to fix the compensation for the acquisition, publication in the Government Gazette for taking over of land for the construction of the project, and transfer of land to the government/owner for the construction of the ROB. Each one of the above activity involves considerable time and effort. The success of land acquisition depends upon the willingness of the land owners to transfer their land for the project. Otherwise, the owners approach the court for legal remedy. This involves enormous time and leads to time delay and cost overrun of the ROB project. Absence of coordination and lack of coordination in planning and execution of various activities of the stakeholders could also cause time delay and cost overrun of the ROB project.

Legal requirements such as environmental impact assessment, obtaining permission from coastal regulatory authority, if the ROB falls near coastline, and conducting social impact studies will also lead to time delay and cost overrun of the ROB project.

\section{CONCLUSIONS}

The purpose of this study was to identify the causes of time delay and cost overrun of ROB projects in India. The 29 causes identified were ranked, grouped, and analysed. The five top most factors identified as responsible for causing time delay and cost overrun of ROB construction projects in the order of significance are: (i) land acquisition, (2) many stakeholders, (3) displacement of network, (4) legal requirements, and (5) claims and disputes. The Spearmen rank correlation among various categories of respondents shows that there is a considerable degree of 
agreement on the ranking of causes. The grouping of 22 causes using factor analysis resulted into 7 factors as (i) cost, payment, price, and contract, (ii) planning, (iii) bidding, (iv) mismanagement and discrepancies, (v) extraneous factors, (vi) project implementation, and (vii) land acquisition and legal hurdles.

This study reveals that ROB construction projects in India is a highly complex process and requires proactive decisions on the part of all stakeholders to effectively foresee and address the entire construction process systematically so that time delay and cost overrun could effectively be reduced drastically, if not avoided.

\section{LIMITATIONS}

This study is limited to the construction of ROB projects in India and to the methods of conducting questionnaire survey, calculation of frequency of responses using frequency index, ranking using Spearman ranking correlation, and computation of factors using factor analysis. Furthermore, this study is also limited to the selection of available and willing owners, contractors, and consultants. It is possible that a different set of methods of data collection and analysis might yield slightly different results and perspectives.

\section{ACKNOWLEDGEMENTS}

Authors would like to thank the engineers of the Department of Highways (Government of Tamil Nadu), Ministry of Railways (Government of India), National Highways Authority of India (Government of India), Ministry of Road Transport and Highways (Government of India), contractors registered with Department of Highways (Government of Tamil Nadu), Ministry of Railways, (Government of India), engineers of Larsen \& Toubro, ECC Division Chennai, and engineering consultants for their valuable support in this research study.

\section{REFERENCES}

Akoa, B.B. (2011). Cost overruns and time delays in highway and bridge projects in developing countries - experiences from Cameroon. MS diss., Michigan State University.

Choudhry, R.M., Nasir, A.R. and Gabriel, H.F. (2012). Cost and time overruns in highway projects in Pakistan. Pakistan Engineering Congress, Centenary Celebration, Paper No 726, 353-369.

Dutta, A. and Dutta, P. (2015). Causes of time and cost overruns in transportation sector projects in Bangladesh. International Journal of Economics and Management Studies, 2(4): 15-17.

Flyvbjerg, B., Holm, M.K.S. and Buhl, S.L. (2004). What causes cost overrun in transport infrastructure transport projects? Transport Reviews, 24(1): 3-18. https://doi. org/10.1080/0144164032000080494a

Fugar, F. and Baah, A. (2010). Delays in building construction projects in Ghana. Australasian Journal of Construction Economics and Building, 10(1/2): 103116. https://doi.org/10.5130/AJCEB.v10i1-2.1592 
Ghasemi, A. and Zahedias, S. (2012). Normality tests for statistical analysis: A guide for non-statisticians. International Journal of Endocrinology and Metabolism, 10(2): 486-489. https://doi.org/10.5812/ijem.3505

Honrao, Y. and Desai, D.B. (2015). Study of delay in execution of infrastructure projects - highway construction. International Journal of Scientific and Research Publications, 5(6): 1-8.

Kishore, M., Rao, C.H. and Singh, L. (2012). Time and cost overrun analysis on national highway development projects. Journal of the Indian Roads Congress, 73(3): 299-321.

Le-Hoai, L., Lee, Y.D. and Lee, J.Y. (2008). Delay and cost overruns in Vietnam large construction projects: A comparison with other selected countries. KSCE Journal of Civil Engineering, 12(6): 367-377. https://doi.org/10.1007/s12205008-0367-7

Mahamid, I. and Bruland, A. (2012). Cost deviation in road construction projects: The case of Palestine. Australian Journal of Construction Economics and Building, 12(1): 58-71. https://doi.org/10.5130/ajceb.v12i1.2427

Patil, S.K., Gupta, A.K., Desai, D.B. and Sajane, A.S. (2013). Causes of delay in Indian transportation infrastructure projects. International Journal of Research in Engineering and Technology, 2(11): 71-80. https://doi.org/10.15623/ ijret.2013.0211013

Ramanathan, C., Narayanan, S.P. and Idrus, A. (2012). Construction delays causing risks on time and cost - a critical review. Australian Journal of Construction Economics and Building, 12(1): 37-57. https://doi.org/10.5130/ajceb. V12i1.2330

Singh, R. (2009). Delays and cost overruns in infrastructure projects: An enquiry into extents, causes and remedies, working paper no. 181. Delhi: Centre for Development Economics, Department of Economics, Delhi School of Economics.

Yong, A.G. and Pearce, S. (2013). A beginner's guide to factor analysis: Focusing on exploratory factor analysis. Tutorials in Quantitative Methods for Psychology, 9(2): 79-94. https://doi.org/10.20982/tqmp.09.2.p079

Wijekoon, S.B. and Attanayake, A.M.C.T.K. (2012). Study on the cost overruns in road construction projects in Sri Lanka. International Conference on Sustainable Built Environment, Sri Lanka, Paper No 69. The Earls Regency Hotel, Kandy, 14-16 December 2012. Sri Lanka: University of Peradeniya.

Williams, B., Brown, T. and Onsman, A. (2010). Exploratory factor analysis: A five-step guide for novices. Australian Journal of Paramedicine, 8(3): 1-13. 